НАУКОВИЙ ВІСНИК

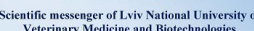

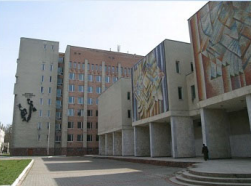

СЕРЯя: ВЕТРРИНАРНН НАУКИ

Том 22 № 100

2020
Науковий вісник Дьвівського національного університету ветеринарної медицини та біотехнологій імені С.3. Гжицького. Серія: Ветеринарні науки

\author{
Scientific Messenger of Lviv National University
} of Veterinary Medicine and Biotechnologies. Series: Veterinary sciences

UDC 636.09:995.122

\title{
The intensity of the processes of lipid peroxidation in the blood of cows in experimental fasciolosis
}

D. V. Freiuk, V. V. Stybel

Stepan Gzhytskyi National University of Veterinary Medicine and Biotechnologies Lviv, Lviv, Ukraine

Article info

Received 26.10.2020

Received in revised form 26.11 .2020

Accepted 27.11.2020

Stepan Gzhytskyi National University of Veterinary Medicine and Biotechnologies, Pekarska, Str., 50, Lviv, 79010, Ukraine.

Tel.: +38-097-448-24-11

E-mail:frejukdima@gmail.com
Freiuk, D. V., \& Stybel, V. V. (2020). The intensity of the processes of lipid peroxidation in the blood of cows in experimental fasciolosis. Scientific Messenger of Lviv National University of Veterinary Medicine and Biotechnologies. Series: Veterinary sciences, 22(100), 151-155. doi: $10.32718 /$ nvlvet10025

Among the most common pathologies of parasitic etiology in ruminants, trematode diseases, namely fasciolosis, occupy a prominent place in terms of the degree of damage and economic damage caused. Activation of lipid peroxidation processes plays a significant role in the mechanisms of the development of fasciolosis in animals. The research aimed to investigate the level of lipid peroxidation products in cows' blood in experimental fasciolosis. For the test, 12 cows of 4-5 years of age, black-spotted breed, were selected, from which 2 groups were formed, six animals in each. Animals in the control group were clinically healthy. Animals of the experimental group were experimentally infected with adolescents. During the research, the rules of compulsory experiments were followed - selecting and keeping analog animals in groups. The cows' diet was balanced in terms of nutrients and minerals. Based on the studies, it was found that after the experimental infestation of cows of the experimental group with the causative agent of fasciolosis, an increase in the level of diene conjugates of their blood on the 15th day of the experiment by $30.3 \%$, and on the 25 th day - by $50.4 \%$ relative to the control group. There was also an increased level of lipid hydroperoxides in their blood, where, respectively, on the 10th and 15th day of the experiment, this figure increased by 18.3 and $32.9 \%$ compared with the control group. On the 25th day of the experiment, the level of lipid hydroperoxides in the blood of cows of the experimental group was the highest. Compared with the control group, it increased by $46.6 \%$, respectively. In the study of the final products of lipid peroxidation, it was found that on the 10th day of the test, the level of TBA-active products in infected cows of the experimental group increased by $9.5 \%$. On the 15th and 20th days of the experiment, the level of end products of LPO in the experimental group's blood of animals was higher by 20.3 and $26.0 \%$ relative to the control group. The increase in TBA-active products' level reflects the activation of peroxide processes in animals with experimental fasciolosis. Therefore, in the clinical manifestation of fasciolosis, parasites secrete metabolic products that promote the formation of free radicals, which in turn enhance the initiation of lipid peroxidation processes.

Key words: parasitology, fasciolosis, ruminants, lipid peroxidation processes.

\section{Інтенсивність процесів пероксидного окиснення ліпідів у крові корів за експериментального фасціольозу}

\author{
Д. В. Фреюк, В. В. Стибель
}

Львівський національний університет ветеринарної медицини та біотехнологій імені С. 3. Гжицького, м. Львів, Україна

Серед найбільш поширених патологій паразитарної етіології у жуйних тварин чільне місие за ступенем ураження та заподіяними економічними збитками займають трематодозні захворювання, а саме фасиіольоз. У механізмах розвитку фасиіольозу у тварин суттєву роль відіграє активачія прочесів пероксидного окиснення ліпідів. Метою роботи було дослідити рівень продуктів 
пероксидного окиснення ліпідів у крові корів за експериментального фасиіольозу. Для дослідів було відібрано 12 корів 4-5-річного віку, чорно-рябої породи, з яких сформовано 2 групи, по шість тварин у кожній. Тварини контрольної групи були клінічно здоровими. Тварини дослідної групи були експериментально заражені адолескаріями. За проведення досліджень дотримувалися правил, обов'язкових щзодо виконання дослідів - підбору та утримання тварин-аналогів у групах. Раціон корів був збалансований за поживними та мінеральними речовинами. На основі проведених досліджень встановлено, цио після експериментального інвазування корів дослідної групи збудником фасиіольозу, встановлено підвищення рівня дієнових конюгатіву їх крові на 15 добу досліду на 30,3 \%, а на 25 добу - на 50,4\% відносно контрольної групи тварин. Також встановлено підвищений рівень гідроперекисів ліпідів у їх крові, де відповідно на 10 і 15 доби досліду даний показник зріс на 18,3 і 32,9\% порівняно з контрольною групою. На 25 добу досліду рівень гідроперекисів ліпідів у крові корів дослідної групи був найвищим, де порівняно з контрольною групою він зріс на 46,6 \% відповідно. При дослідженні кінцевих продуктів пероксидного окиснення ліпідів встановлено, щуо на 10 добу досліду рівень ТБКактивних продуктів у інвазованих корів дослідної групи зріс на 9,5\%. На 15 і 20 доби досліду рівень кіниевих продуктів ПОЛ у крові тварин дослідної групи був вищим на 20,3 і 26,0% відносно контрольної групи. Підвищення рівня ТБК-активних продуктів відображає активацію пероксидних прочесів у тварин за експериментального фасиіольозу. Отже за клінічного прояву фасиіольозу паразити виділяють продукти метаболізму, які сприяють утворенню вільних радикалів, щзо у свою чергу посилюють ініціацію процесів пероксидного окиснення ліпідів.

Ключові слова: паразитологія, фасиіольоз, жуйні, процеси пероксидного окиснення ліпідів.

\section{Ветуп}

Ліпіди виконують важливу роль у формуванні механізмів адаптації організму тварин до умов навколишнього середовища (Lesyk et al., 2020). У механізмах розвитку фасціольозу у тварин суттєву роль відіграє активація процесів пероксидного окиснення ліпідів (Kulyaba et al., 2016; 2017; 2019; Chernushkin et al., 2020). Дані процеси є життєво важливою ланкою в регуляції ліпідного складу біомембран і мембрановмісних ензимів (Gutyj et al., 2017). Активація процесів пероксидного окиснення ліпідів $є$ універсальним наслідком впливу на живу систему різноманітних екстремальних агентів, результат окисного катаболізму складних органічних структур (Calabrese et al., 2005; Kausar et al., 2018). За фізіологічних умов пероксидне окиснення ліпідів сприяє оновленню ліпідних компонентів в організмі, а інтенсифікація вільнорадикальних процесів впливає на вміст загальних ліпідів та на співвідношення їх окремих класів. Окислення ліпідів призводить до пошкодження мембранних структур, порушення їхньої проникності для іонів (CunhaOliveira et al., 2020; Slivinska et al., 2020). Стаціонарний рівень пероксидного окиснення ліпідів $є$ характерним для метаболізму всіх нормальних тканин, а також $€$ одним із процесів швидкої модифікації властивостей біологічних мембран і мембранозалежних метаболічних реакцій та $є$ первинним індуктором в адаптаційній перебудові організму корів під час екстремальних впливів (Grymak et al., 2020; Said et al., 2020), в тому числі розвитку фасціольозу.

За таких умов важливе значення має вивчення рівня продуктів пероксидного окиснення ліпідів у крові інвазованих корів, які вказують на посилення чи пригнічення процесів ПОЛ.

Саме тому метою роботи було дослідити рівень продуктів пероксидного окиснення ліпідів у крові корів за експериментального фасціольозу.

\section{Матеріали і методи досліджень}

Усі маніпуляції з тваринами проводили відповідно до Європейської конвенції про захист хребетних тварин, які використовуються для експериментальних і наукових цілей (Official Journal of the European Union L276/33, 2010). Для дослідів було відібрано 12 корів 4-5-річного віку, чорно-рябої породи, з яких сформовано 2 групи, по шість тварин у кожній. Тварини контрольної групи (К) були клінічно здоровими. Тварини дослідної групи (Д) були експериментально заражені адолескаріями. За проведення досліджень дотримувалися правил, обов'язкових щодо виконання дослідів підбору та утримання тварин-аналогів у групах. Раціон корів був збалансований за поживними та мінеральними речовинами.

Кров для аналізу брали $з$ яремної вени до зараження та на 5-, 10-, 15-, 20-, 25- і 30-у добу досліду.

Визначення вмісту дієнових кон'юzатів. В основі методу лежить властивість молекул жирних кислот iз двома подвійними спряженими зв'язками інтенсивно поглинати світло за довжини хвилі $\lambda=233$ нм.

У пробірки вносили 0,2 мл плазми крові та додавали 1,8 мл суміші н-гептан-ізопропанол. Закривали корками на 15 хв. Центрифугували за умови 6000 об/хв упродовж 10 хв. 3 надосадової рідини відділяли гептанову фазу (верхній шар), 0,5 мл якої вносили у пробірки 32 мл етилового спирту. Оптичну густину вимірювали на спектрофотометрі за довжини хвилі 233 нм проти н-гептану (Vlizlo, 2012).

Для визначення кількості дієнових кон'югатів використовували коефіцієнт молярної екстинкції $2,2 \times 10^{5}$ моль $^{-1} \mathrm{~cm}^{-1}$.

Концентрацію дієнових кон'югатів (ДК), виражену в мкмоль/л, розраховували за формулою:

$$
A=\frac{(Д E-K E) \cdot 103}{c}
$$

де:

$A$ - кількість дієнових кон'югатів у мкмоль/л;

$c$ - кількість білка в пробі, мг;

$K E$ - екстинкція контрольної проби;

Визначення вмісту ТБК-активних продуктів. Метод базується на реакції між малоновим діальдегідом (МДА) і тіобарбітуровою кислотою (ТБК), яка за високої температури і кислому середовищі протікає 3 утворенням кольорового комплексу, що містить одну молекулу МДА і дві молекули ТБК (Vlizlo, 2012).

До 0,5 мл гомогенату тканини додавали 5 мл $20 \%$ ної фосфорвольфрамової кислоти, пробірки закривали корками, перемішували і витримували на холоді 15 хв. Центрифугували за $4{ }^{\circ} \mathrm{C}$ протягом 15 хв за 2500 об/хв. Надосадову рідину зливали, а до осаду 
додавали 2 мл води і 0,8 \%-ної ТБК. Інкубували 1 год на водяній бані за $100^{\circ} \mathrm{C}$. Охолоджували в холодній воді. Центрифугували 10 хв за умови 6000 об/хв. У центрифугаті вимірювали оптичну густину на спектрофотометрі за довжини хвилі 535 і 580 нм, щоб запобігти поглинанню зафарбованих комплексів ТБКречовинами не ліпідної природи. Вміст ТБК-активних продуктів розраховували за допомогою рівняння регресії:

$$
\mathrm{C}=0,21+26,5 \Delta \text { Д }
$$

де $\mathrm{C}$ - концентрація ТБК-активних продуктів, нмоль/г тканини; $\Delta$ Д - показник Д $535-Д_{580}$ в центрифугаті (в од. оптичної густини).

Визначення вмісту гідроперекисів ліпідів. Визначення вмісту гідроперекисів ліпідів у біологічному матеріалі досягається осадженням білків розчином трихлороцтової кислоти (ТХОК) та екстракцією ліпідів етанолом $з$ наступною взаємодією досліджуваних екстрактів 3 тіоцианатом амонію (Vlizlo, 2012).

Забір тканини і виготовлення проб для екстрагування проводять при $\mathrm{t}<4{ }^{\circ} \mathrm{C} .0,2$ мл плазми крові, яка містить 0,5 мг/мл оксалату натрію в буферному розчині $\mathrm{pH} 7,4$, поміщають в центрифужну пробірку 3 добре фіксованим корком, додають 2,8 мл етанолу і 0,05 мл $50 \%$ розчину ТХОК. Пробірку закривають і струшують протягом 5-6 хв. Утворений білковий осад виділяють центрифугуванням протягом 10 хв при 3000 об/хв.

Одержаний супернатант, який являє собою етанольний екстракт ліпідів, використовують як об'єкт для визначення гідроперекисів ліпідів і загальних ліпідів, які містять поліненасичені жирні кислоти.

Визначення гідроперекисів ліпідів: 1,5 мл етанольного екстракту доводять етанолом до 2,7 мл, струшують i додають 0,02 мл концентрованої НCI i 0,03 мл $1 \%$ розчину солі Мора в $3 \%$ розчині НCI. Вміст струшують і через 30 с додають 0,2 мл $20 \%$ розчину тіоцианату амонію, після чого розвивається малинове забарвлення. Вимірювання оптичної густини проводять протягом 10 хв після додавання тіоцианату амонію на спектрофотометрі при довжині хвилі 480 нм. Контрольну пробу ставлять як дослідну, але замість плазми крові беруть 0,2 мл бідистильованої води.

Вміст гідроперекисів ліпідів у біологічному матеріалі виражають в величинах оптичної густини при 480 нм на 1 мл плазми крові ( $\Delta Д_{480} /$ мл плазми):

$\Delta Д_{480}$ (гідроперекисів ліпідів) $=Д_{480}($ дослід) Д $_{480}$ (контроль).

Аналіз результатів досліджень проводили за допомогою пакету програм Statistica 6.0. Вірогідність різниць оцінювали за t-критерієм Стьюдента. Результати вважали вірогідними при $\mathrm{P} \leq 0,05$.

\section{Результати та їх обговорення}

На основі проведених досліджень встановлено, що рівень дієнових кон'югатів на початку досліду коливався у межах 5,76 $\pm 0,12-5,73 \pm 0,13$ мкмоль/л. Після експериментального інвазування корів дослідної групи збудником фасціольозу встановлено підвищення його рівня на 10 добу досліду на $11,2 \%$, а на 15 добу - на 30,3 \% відносно контрольної групи тварин. У подальшому рівень дієнових кон'югатів у крові корів дослідної групи продовжував зростати і відповідно на 20 добу досліду він становив $8,12 \pm 0,19$ мкмоль/л. На 25 добу досліду встановлено підвищення рівня дієнових кон'югатів на 50,4 \% порівняно $з$ показниками контрольної групи. На 30 добу досліду рівень досліджуваного показника дещо знизився порівняно з попередньою добою, однак порівняно $з$ контрольною групою він був вищим на $50 \%$ (рис. 1).

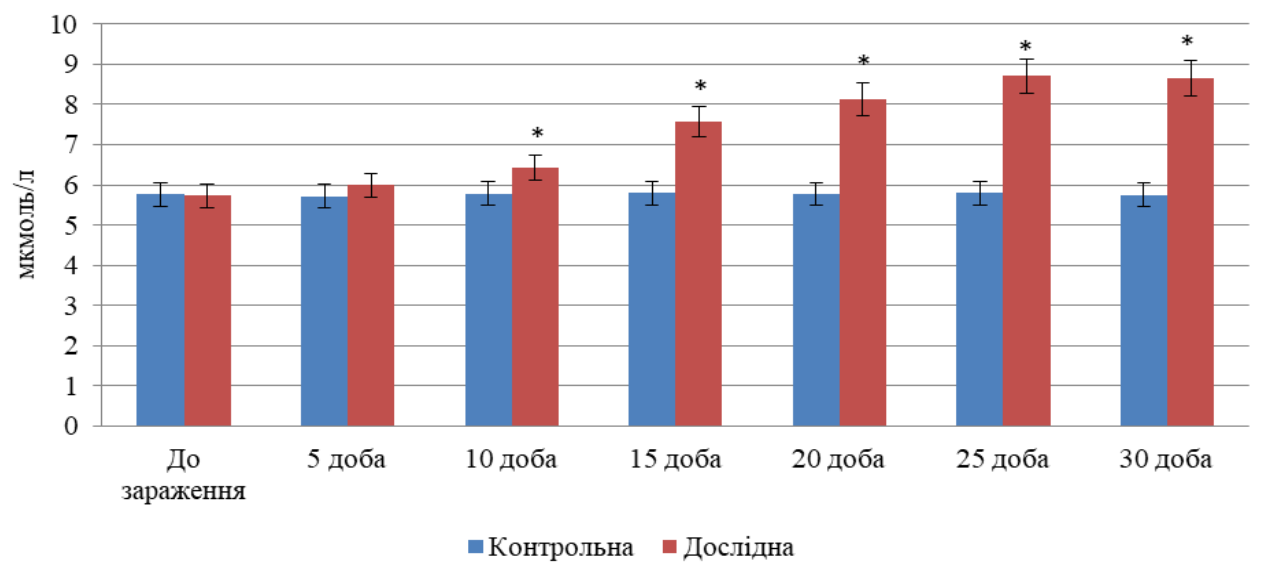

Рис. 1. Рівень дієнових кон'югатів у крові корів за експериментального фасціольозу $(\mathrm{M} \pm \mathrm{m}, \mathrm{n}=6)$

Відомо, що з ліпідним обміном тісно пов'язане пероксидне окиснення ліпідів, яке призводить до утворення гідроперекисів, які за підвищенного рівня здатні руйнувати мембрани і органели клітин та біополімери, що спричиняє в організмі розвитку ряд патологій і внутрішньоклітинні дисфункції. При дослідженні рівня гідроперекисів ліпідів у крові корів контрольної та дослідної груп даний показник становив $2,08 \pm 0,03-2,10 \pm 0,04$ од.Е 480/мл. За інвазування корів збудником фасціольозу встановлено підвищений рівень гідроперекисів ліпідів у їх крові, де відповідно на 10 і 15 доби досліду даний показник зріс на 
18,3 і 32,9 \% порівняно з контрольною групою. На 20 добу досліду рівень гідроперекисів ліпідів у крові дослідної групи зріс до 2,89 $\pm 0,07$ од.Е 480/мл, тоді як у контрольної групи тварин він становив $2,10 \pm 0,03$ од.Е 480/мл. На 25 добу досліду рівень гідроперекисів ліпідів у крові корів дослідної групи був найвищим, де порівняно 3 контрольною групою він зріс на 46,6 \% відповідно. На 30 добу досліду рі- вень гідроперекисів ліпідів у крові тварин дослідної групи рівень проміжних продуктів ПОЛ зріс на 40,7\% (рис. 2).

При дослідженні кінцевих продуктів ПОЛ встановлено, що на 5 добу досліду рівень ТБК-активних продуктів у крові корів контрольної групи становив $4,86 \pm 0,09$ нмоль/мл, тоді як у дослідної групи 4,92 $\pm 0,11$ нмоль/мл (рис. 3).

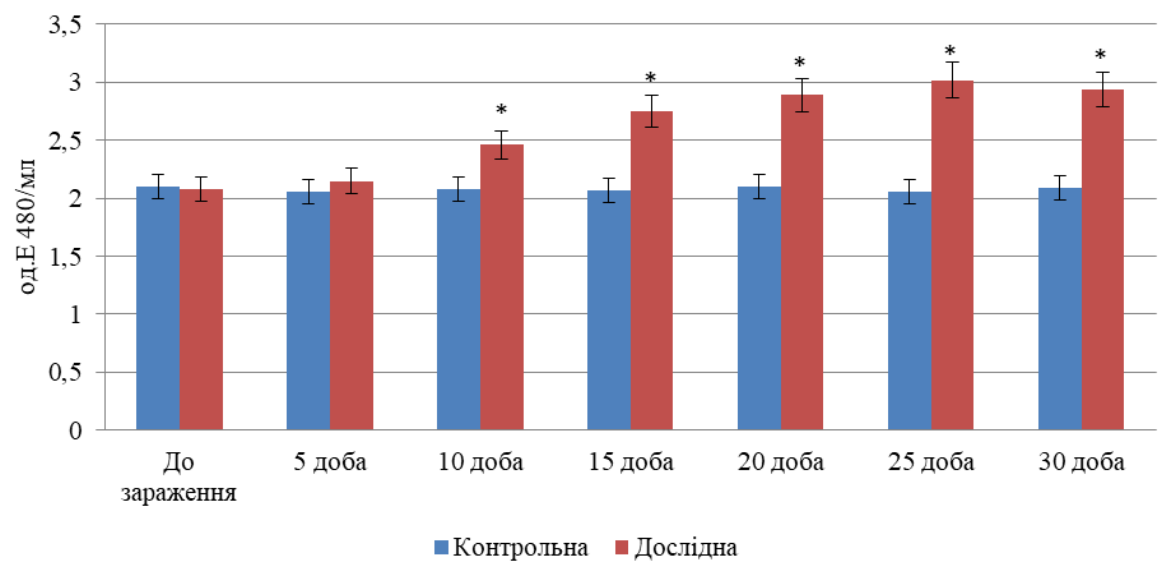

Рис. 2. Рівень гідроперекисів ліпідів у крові корів за експериментального фасціольозу $(\mathrm{M} \pm \mathrm{m}, \mathrm{n}=6)$

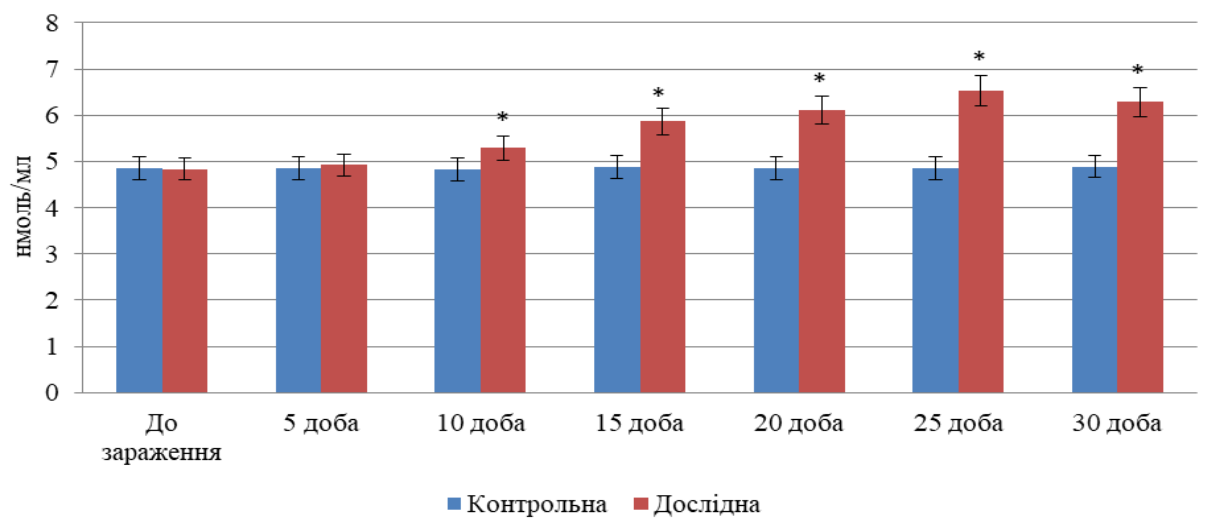

Рис. 3. Рівень ТБК-активних продуктів у крові корів за експериментального фасціольозу $(\mathrm{M} \pm \mathrm{m}, \mathrm{n}=6)$

На 10 добу досліду встановлено підвищений рівень ТБК-активних продуктів у інвазованих корів дослідної групи, де порівняно з контрольною групою він зріс на 9,5 \%. На 15 і 20 доби досліду рівень кінцевих продуктів ПОЛ у крові тварин дослідної групи був вищим на 20,3 і 26,0 \% відносно контрольної групи. Підвищення рівня ТБК-активних продуктів відображає активацію пероксидних процесів у тварин за експериментального фасціольозу. Найвищим рівень ТБК-активних продуктів був у крові корів дослідної групи на 25 добу досліду, де відповідно він становив 6,54 \pm 0,13 нмоль/мл, що на 34,6 \% був вищим за контроль. На 30 добу досліду рівень кінцевих продуктів ПОЛ у крові корів дослідної групи був вірогідно вищим за контрольні величини.

\section{Висновки}

За клінічного прояву хвороби паразити виділяють продукти метаболізму, які сприяють утворенню віль- них радикалів, що у свою чергу посилюють ініціацію процесів пероксидного окиснення ліпідів. На це вказує зростання продуктів пероксидного окиснення ліпідів: дієнових кон'югатів, гідроперекисів ліпідів, ТБК-активних продуктів.

Перспективи подальших досліджень. У подальшому планується дослідити стан антиоксидантного захисту організму корів за експериментального фасціольозу.

\section{References}

Calabrese, V., Lodi, R., Tonon, C., D'Agata, V., Sapienza, M., Scapagnini, G., Mangiameli, A., Pennisi, G., Stella, A. M., Butterfield, D. A. (2005). Oxidative stress, mitochondrial dysfunction and cellular stress response in Friedreich's ataxia. J Neurol Sci, 233(1-2), 145-162. doi: 10.1016/j.jns.2005.03.012.

Chernushkin, B. O., Vlizlo, V.V., Slivinska, L. G., Gutyj, B. V., Shcherbatyy, A. R., Maksymovych, I. A., Leno, 
M. I., Rusyn, V. I., Lychuk, M. H., Fedorovych, V. L., Lukashchuk, B. O., Zinko, H. O., \& Prystupa, O. I. (2020). Treatment strategies for sheep with acute yellow athrophy of the liver caused by the fasciolosis. Ukrainian Journal of Ecology, 10(2), 294-301. doi: $10.15421 / 2020100$.

Cunha-Oliveira, T., Montezinho, L., Mendes, C., Firuzi, O., Saso, L., Oliveira, P. J., \& Silva, F. S. G. (2020). Oxidative Stress in Amyotrophic Lateral Sclerosis: Pathophysiology and Opportunities for Pharmacological Intervention. Oxid Med Cell Longev, 2020, 5021694. doi: 10.1155/2020/5021694.

Grymak, Y., Skoromna, O., Stadnytska, O., Sobolev, O., Gutyj, B., Shalovylo, S., Hachak, Y., Grabovska, O., Bushueva, I., Denys, G., Hudyma, V., Pakholkiv, N., Jarochovich, I., Nahirniak, T., Pavliv, O., Farionik, T., \& Bratyuk, V. (2020). Influence of "Thireomagnile" and "Thyrioton" preparations on the antioxidant status of pregnant cows. Ukrainian Journal of Ecology, 10(1), 122-126. doi: 10.15421/2020_19.

Gutyj, B., Khariv, I., Binkevych, V., Binkevych, O., Levkivska, N., Levkivskyj, D., \& Vavrysevich, Y. (2017). Research on acute and chronic toxity of the experimental drug Amprolinsyl. Regulatory Mechanisms in Biosystems, 8(1), 41-45. doi: 10.15421/021708.

Kausar, S, Wang, F, \& Cui, H. (2018). The role of mitochondria in reactive oxygen species generation and Its implications for neurodegenerative diseases. Cells, 7(12), 274. doi: 10.3390/cells7120274.

Kulyaba, O. V., Stybel, V. V., \& Gutyj, B. V. (2016). The influence of clozaverm A and catozal on antioxidant status of cows organism for the experimental fasciolosis, sensitized atypical mycobacteria. Scientific Messenger LNUVMB named after S. Z. Gzhytskyj, 18, 2(66), 96-99. doi: 10.15421/nvlvet6621.
Kulyaba, O., Stybel, V., \& Gutyj, B. (2017). The influence of closaverm a and catosal on indicators of protein synthesizing functions of cows liver by experimental fasciolosis, sentsitized by atypical mycobacteria. Scientific Messenger LNUVMBT named after S.Z. Gzhytskyj, 19(73), 122-125. doi: $10.15421 /$ nvlvet 7325 .

Kulyaba, O., Stybel, V., Gutyj, B., Turko, I., Peleno, R., Turko, Ya., Golovach, P., Vishchur, V., Prijma, O., Mazur, I., Dutka, V., Todoriuk, V., Golub, O. Dmytriv, O., \& Oseredchuk, R. (2019). Effect of experimental fascioliasis on the protein synthesis function of cow liver. Ukrainian Journal of Ecology, 9(4), 612-615. URL: https://www.ujecology.com/articles/effect-ofexperimental-fascioliasis-on-the-protein-synthesisfunction-of-cow-liver.pdf.

Lesyk, Y., Ivanytska, A., Kovalchuk, I., Monastyrska, S., Hoivanovych, N., Gutyj, B., Zhelavskyi, M., Hulai, O., Midyk, S., Yakubchak, O., \& Poltavchenko,T. (2020). Hematological parameters and content of lipids in tissues of the organism of rabbits according to the silicon connection. Ukrainian Journal of Ecology, 10(1), 30-36. doi: 10.15421/2020 5.

Said, W., Stybel, V., Gutyj, B., \& Prijma, O. (2020). Antioxidant protection system of dog organism at experimental toxocariasis. Bulletin of Poltava State Agrarian Academy, 3, 233-240. doi: 10.31210/visnyk2020.03.27.

Slivinska, L. G., Shcherbatyy, A. R., Lukashchuk, B. O., \& Gutyj, B. V. (2020). The state of antioxidant protection system in cows under the influence of heavy metals. Regulatory Mechanisms in Biosystems, 11(2), 237-242. doi:10.15421/022035.

Vlizlo, V. V. (2012). Laboratorni metody doslidzhen u biologiyi, tvarynnycztvi ta veterynarnij medycyni: dovidnyk. Lviv: Spolom (in Ukrainian). 